\title{
Research on Landscape Pattern Optimization of Xianglan Town Based on GIS and Fragstats
}

\author{
Haihong Song1, a , Lingxiao Liu, b, Yutong Zhang ${ }^{1, c}$ and Siyu Pei ${ }^{1, d}$ \\ ${ }^{1}$ School of civil engeering, Northeast Forestry University, Haibin 150040, China;

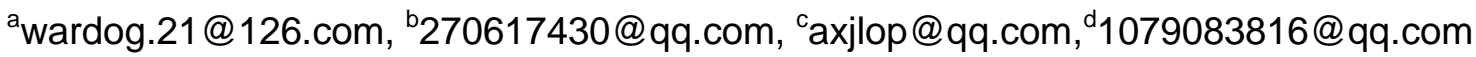

\begin{abstract}
By the principle of landscape ecology analysis to analyze the Heilongjiang Province on the landscape spatial pattern of town domain Tangyuan County in Jiamusi city, Landscape spatial analysis and spatial data modeling were carried out by using GIS technology, and the raster map was transferred into Fragstats to calculate the landscape index, which includes the main index of landscape patch area, total area of patch type, patch density, total edge length, patch area of statistical distribution index, patch index distribution type for landscape area ratio, the largest patch area index, the proportion of similar adjacent degree, degree of polymerization, interspersion and juxtaposition index, patch cohesion index, landscape diversity index and the landscape evenness index, edge density, similarity index, the number of landscape patches, landscape shape index, fractal dimension, and perimeter area fractal dimension. The deficiency of Landscape spatial pattern can be obtained after the landscape index analysis, such as the low traffic land landscape aggregation degree, the complex shape of edge landscape, the high landscape fragmentation degree ; the small waters of landscape patch area, so as to optimize the patch, corridor and matrix planning, to form a reasonable landscape pattern, and to optimize the landscape ecological environment of small towns.
\end{abstract}

Keywords: Xianglan town; Landscape pattern; Spatial analysis; GIS; Optimization.

\section{基于 GIS 和 Fragstats 的香兰镇景观格局优化研究}

\author{
宋海宏 ${ }^{1}$, 刘凌霄 ${ }^{2}$, 张雨桐 ${ }^{1}$, 裴思宇 ${ }^{1}$ \\ (1，2,3,4. 东北林业大学 土木工程学院，黑龙江省 哈尔滨市 150040)
}

摘要: 用景观生态学原理对黑龙江省佳木斯市汤原县香兰镇镇域景观空间格局进行分析, 运用 GIS 技术进行景观空间 分析、空间数据建模，将所得栅格图转入 Fragstats 中进行景观指数计算，所选取的景观指数主要有景观斑块面积、斑块类 型总面积、斑块密度、总边缘长度、斑块面积统计分布指数、斑块类型所占景观面积比例、最大斑块面积指数、相似邻接比 例度、聚合度、散布与并列指数、斑块内聚力指数、景观多样性指数、景观均匀度指数、边缘密度、相似指数、景观斑块数 量、景观形状指数、分维数、周长面积分维数等。对其景观指数进行分析后, 可得出香兰镇景观空间格局的不足之处, 如交 通用地景观聚集度低、景观边缘形态复杂、景观破碎化程度高、水域景观斑块面积小等，从而有针对性地对其斑块、廊道和 基质规划方案进行优化，形成合理的景观格局，优化小城镇景观生态环境。

关键词：香兰镇；景观格局；空间分析；GIS；优化

中图分类号：TU984 文献标志码：A

引言

香兰镇是黑龙江省佳木斯市汤原县西部的乡镇, 分布在山地与平原两大单元地貌接合处, 镇内主要呈 现平原地貌, 黑土与草甸土为其主要土质, 主要水系为汤旺河水系。该地属于温带季风气候, 冬夏风向差 别显著, 季节变化明显, 天气的非周期性变化突出。冬季受温带大陆气团影响, 寒冷干燥, 南北温差大。 夏季受温带海洋气团或变性热带海洋气团控制, 温热多雨, 南北温差小。年降水量 500 $600 \mathrm{~mm}$, 降水主要 集中在 6-8 月份, 超过全年降水量的 70\%。香兰镇镇域面积 132.4 平方公里, 其中耕地面积 72 平方公里, 
旱田面积 58.7 平方公里, 宜牧荒山、荒坡 10 平方公里。全镇共有 26 个村屯，总人口 3.2 万人，其中农 业人口 2.2 万人，占镇内总人口的 $68.7 \%$ 。香兰镇经济繁荣，全镇以农业生产为主，盛产水稻、玉米、大 豆等粮食作物, 农民年人均纯收入 8000 余元。近年来, 区域发展较快, 城镇化、工业化和生活现代化进 程加快，对区域景观构成了较大的冲击，改变着区域景观格局。香兰镇历史文化悠久，是以宋金文化为主 体的文化交融区，现有著名遗址金代 “万户府”，传统文化景观不仅承载其文化脉络更是区域景观的重要 特征。但区域景观的飞速发展改变着原本均质和稳定的景观格局, 呈现出景观破碎化特征。

香兰镇的空间结构采用 “一纵两横，一核多点”的形式。一纵表示沿哈肇路形成镇域一级发展轴，两 横分别表示镇域二级发展轴以及镇域濒水景观轴, 一核表示香兰镇中心城区, 多点表示镇域发展的节点, 分别为陶家村、庆丰村、红星村、共和村。香兰镇内人口超过 1000 的中心村屯共计 6 个, 沿铁路分布, 另外 9 个基层村屯分布在铁路北部, 形成以香兰镇区为核心, 中心村分布在主要交通枢纽的的城镇空间布 局形态。结合其交通枢纽空间布局, 镇内路网形成两横三纵的 “井一环” 的道路骨架。香兰镇内的土地利 用类型主要有仓储用地、工业用地、商业用地、居住用地及医疗用地。其中仓储用地沿铁道布置, 工业用 地设置在仓储用地的北侧, 主要的商业用地沿着镇区主要道路进行布置, 其余用地则分布在铁路的南侧。 镇内主要服务设施均根据居住用地进行规划, 主要布置在铁路以南, 其中包括行政办公、文化设施教育科 研用地等。在城镇产业发展方面，香兰镇形成了 “一轴一带四区” 的城镇产业空间布局，一轴即依托绥佳 铁路形成的农业产业发展主轴, 一带为汤旺河休闲观光经济带, 四区即文化休闲旅游经济区、畜牧产业区、 示范农业产业区以及农产品种植加工产业区。

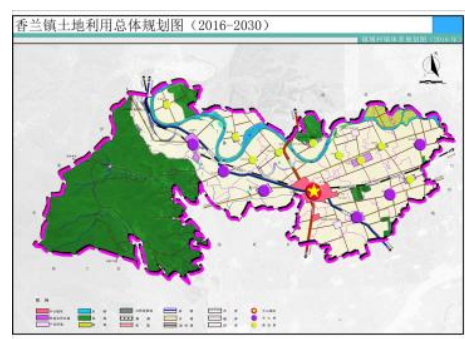

\section{1 研究方法}

\section{1 基本概念}

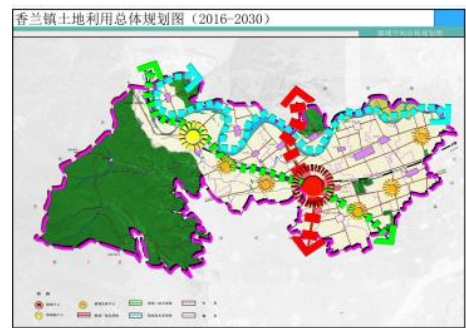

图 1 香兰镇土地利用整体规划图

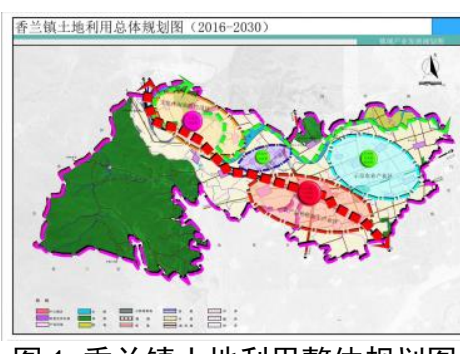

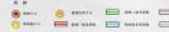

景观格局是景观生态学研究的重要内容之一。 ${ }^{[1]}$ 景观格局是指景观要素在空间上分散或聚集的展布, 它是景观组分的空间分布和组合特征的表现，是在景观内部的自然条件约束和人为活动影响双重作用下， 为了适应特定的景观功能要求而形成的一种景观整体结构。景观格局通常是站在景观尺度上考虑问题。从 空间格局出发, 探讨空间格局与生态过程或系统功能之间的关系, 已成为景观生态学研究的主要思路, 因 此, 定量空间格局是景观生态学研究的基础 ${ }^{[2]}$ 。在进行景观格局分析之前要明确所选择的景观指数, 景观 格局指数可分为斑块水平指数、斑块类型水平指数、景观水平指数 ${ }^{[3]}$ 。景观格局优化则是对景观格局、功 能和过程综合理解的基础上，对各景观类型在空间和数量上进行有目的性的优化设计。

\section{2 数据获取与技术路线}

首先将香兰镇现状土地利用 CAD 图在 ArcGIS 中进行点、线、面的数据导出, 再将矢量图转换为栅格 图, 导入 Fragstats 中, 进行景观空间指数的计算，将所生成的景观空间指数绘制成表，进行分类分析。 图 3 为 GIS 中绘制的香兰镇景观格局图。 


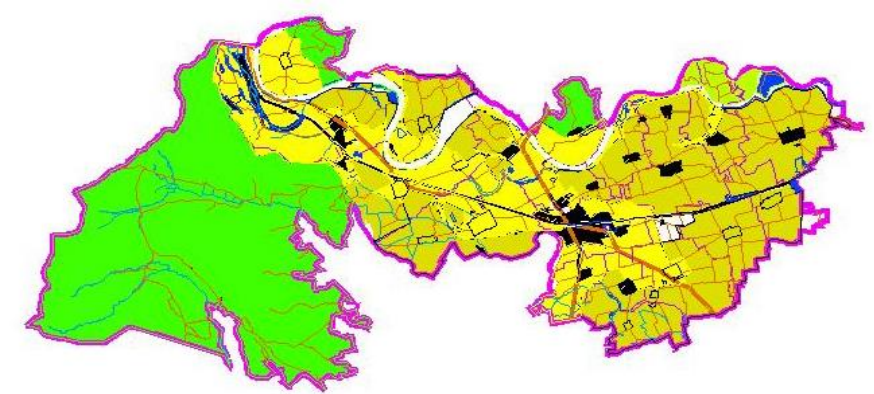

图 2 香兰镇地利用现状图

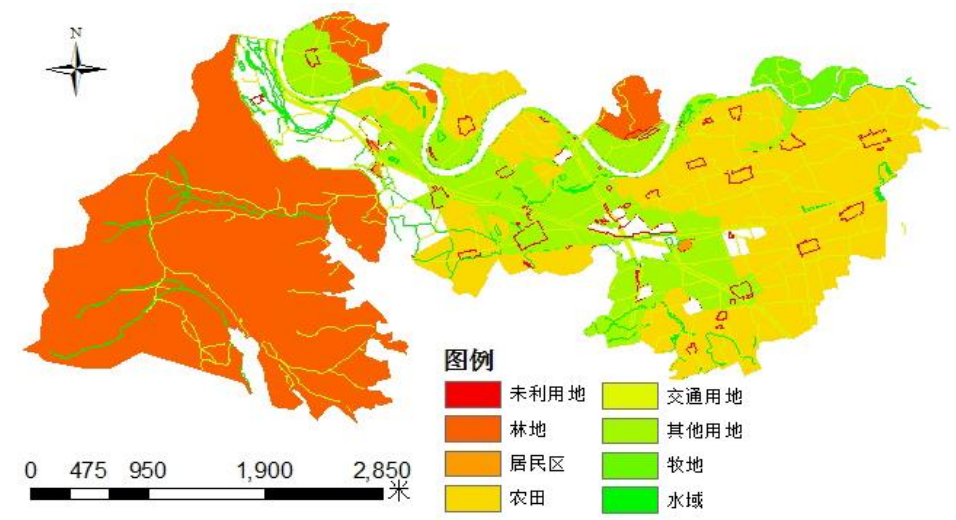

图 3 香兰镇景观类型栅格图

\section{2 景观空间格局分析}

\section{1 景观斑块特征分析}

香兰镇分为 8 个景观类型, 共有 69 个景观斑块, 斑块总面积达 132.4 平方公里。为更直观的展现香 兰镇的景观斑块的情况, 将香兰镇现状土地利用 CAD 图在 ArcGIS 中进行空间分析, 再通过 Fragstats 软 件计算出不同的景观指数, 具体如表 1 。

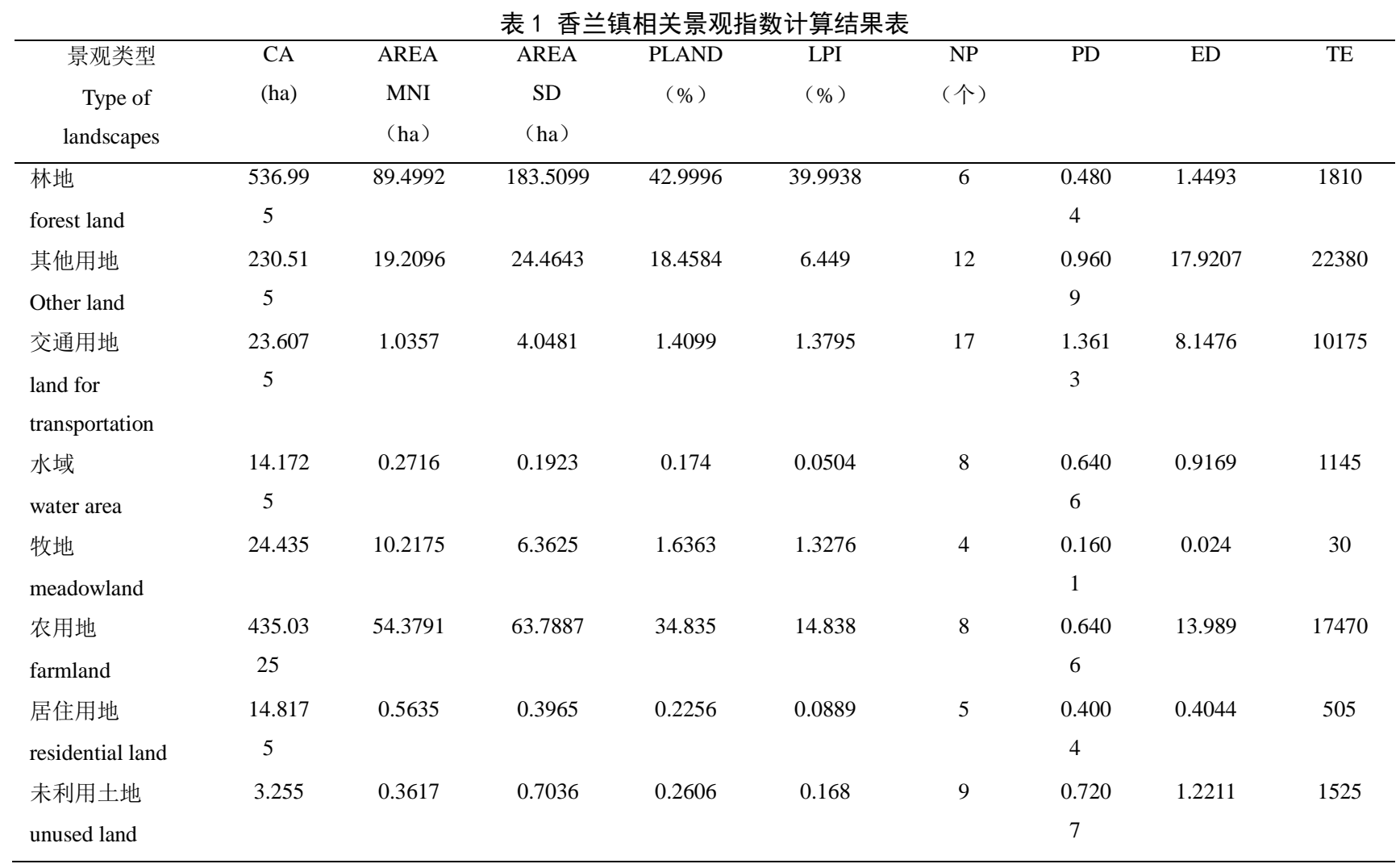


2.1. 1 景观斑块面积分析 ${ }^{[4]}$ 景观斑块类型的总面积 (CA) 在景观空间格局的分析中最为简单、常用，也 是最重要的指数之一。从图 4 中可以看出香兰镇土地利用景观斑块面积最大的是林地, 这与香兰镇北部是 小兴安岭千里群山有关。除此之外, 农用地也占有较大面积比例, 仅次于林地面积。该镇牧地面积适中, 水域面积比例不大。但是居住用地、交通用地和未利用土地面积比例均较小，说明香兰镇居住环境的基础 设施建设比较差, 交通不便利, 配套服务不完全善。未利用土地比例面积远远小于其他用地土地面积, 大 大减少了未来城镇发展的诸多可能性。可见香兰镇的区域规划存在些许问题，可能会对其经济发展起到抑 制作用。

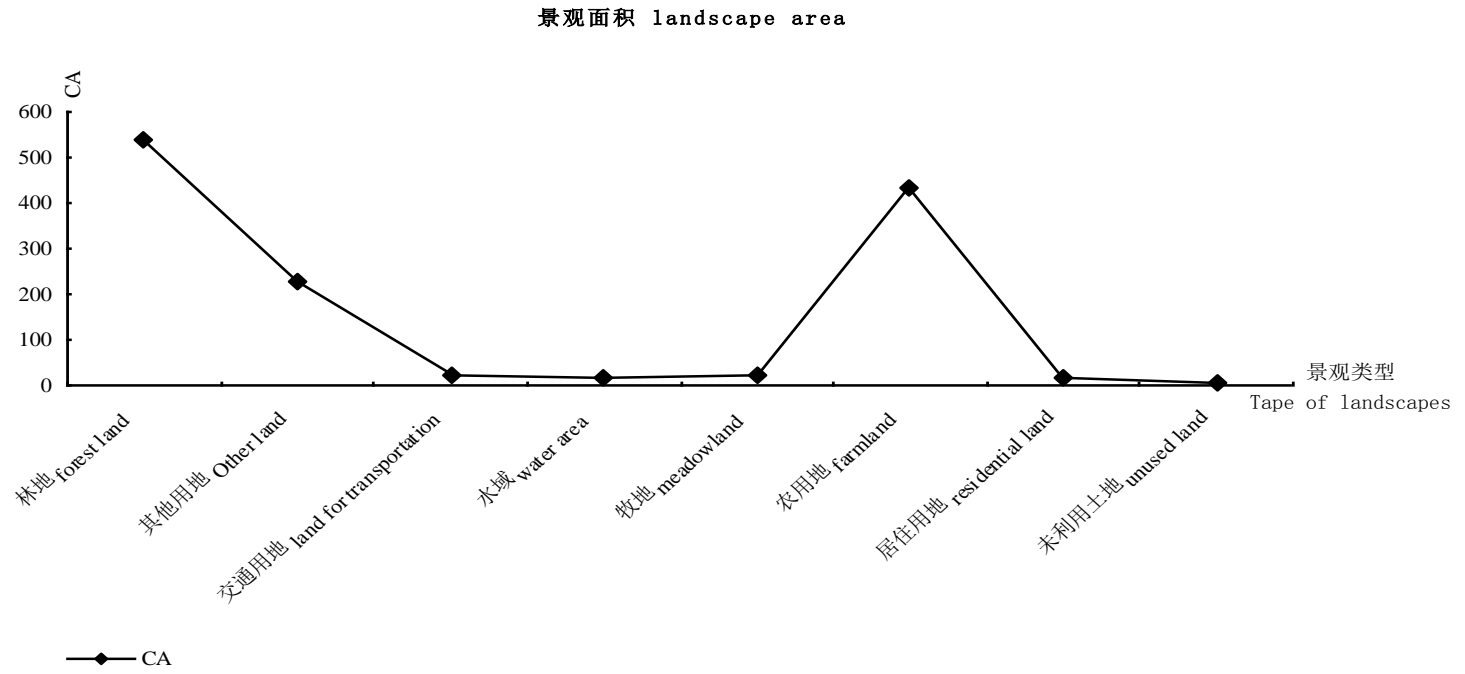

图 4 景观面积折线图

2.1.2 景观斑块平均面积分析 ${ }^{[5]}$ 景观斑块平均面积与景观破碎化程度成反比，是景观粒度的一种表达形 式。从表 1 中可见，林地景观粒度最大，数值达 89.4992ha; 其次是农用地，数值为 54. 3791ha。由此可 见, 林地景观破碎化最低, 农用地次之。未利用土地、居住用地、水域与交通用地景观破碎化程度均较高。

2.1.3 景观斑块面积标准方差分析 根据表 1 中数据可知, 林地的景观斑块面积标准方差最大, 值为 183. 5009ha; 农用地次之，值为 $63.7887 \mathrm{ha}$ 。景观斑块面积标准方差最小的是水域。

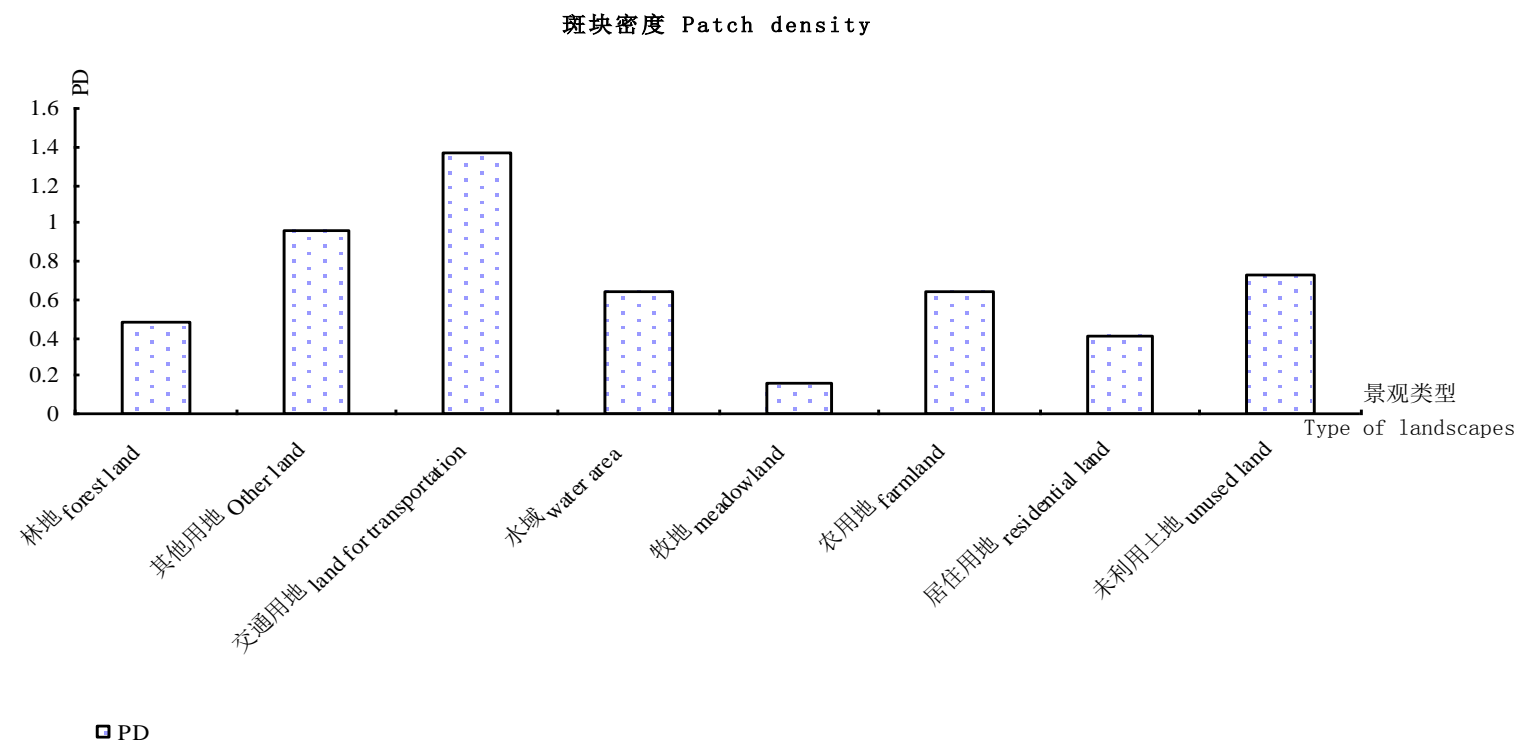

图 5 景观斑块密度柱状图 
2.1.4 景观斑块密度分析 ${ }^{[6]}$ 景观斑块密度反映了土地利用景观斑块空间分布的均匀程度, 其值的大小与 景观的破碎度呈正向关性, 展现出多种生态过程, 因此景观斑块密度常常用来描述整个景观的异质性。从 图 5 中可以清楚的看到, 交通用地景观斑块密度最大, PD 值为 1.3613。说明道路用地是对人类影响最大, 是关系最为密切的用地, 其对城镇景观的发展影响最为显著, 景观的破碎化程度也较高。牧地、林地、居 住用地和未利用土地景观斑块密度较小, 可见人们对这几块土地用地干扰较少, 有待将来进一步开发利用。 2.1.5 景观边缘密度分析 ${ }^{[7]}$ 景观的边缘密度也是对景观破碎化程度的衡量指标之一, 边缘密度主要是对 景观单元组成被分割程度的描述。从表 1 中可以看出, 在香兰镇的所有景观类型中, 其他用地、农用地和 交通用地的景观边缘密度较大, ED 值分别为 17.9207、13.989 和 8.1476。由以上数据可知, 在香兰镇景 观中, 其他用地、农用地和交通用地景观被边缘割据的程度较大, 其中其他用地景观被边缘割据的程度最 高, 反映出其分布不均衡的特点。其余景观类型景观边缘密度值适中, 被边缘分割不明显。

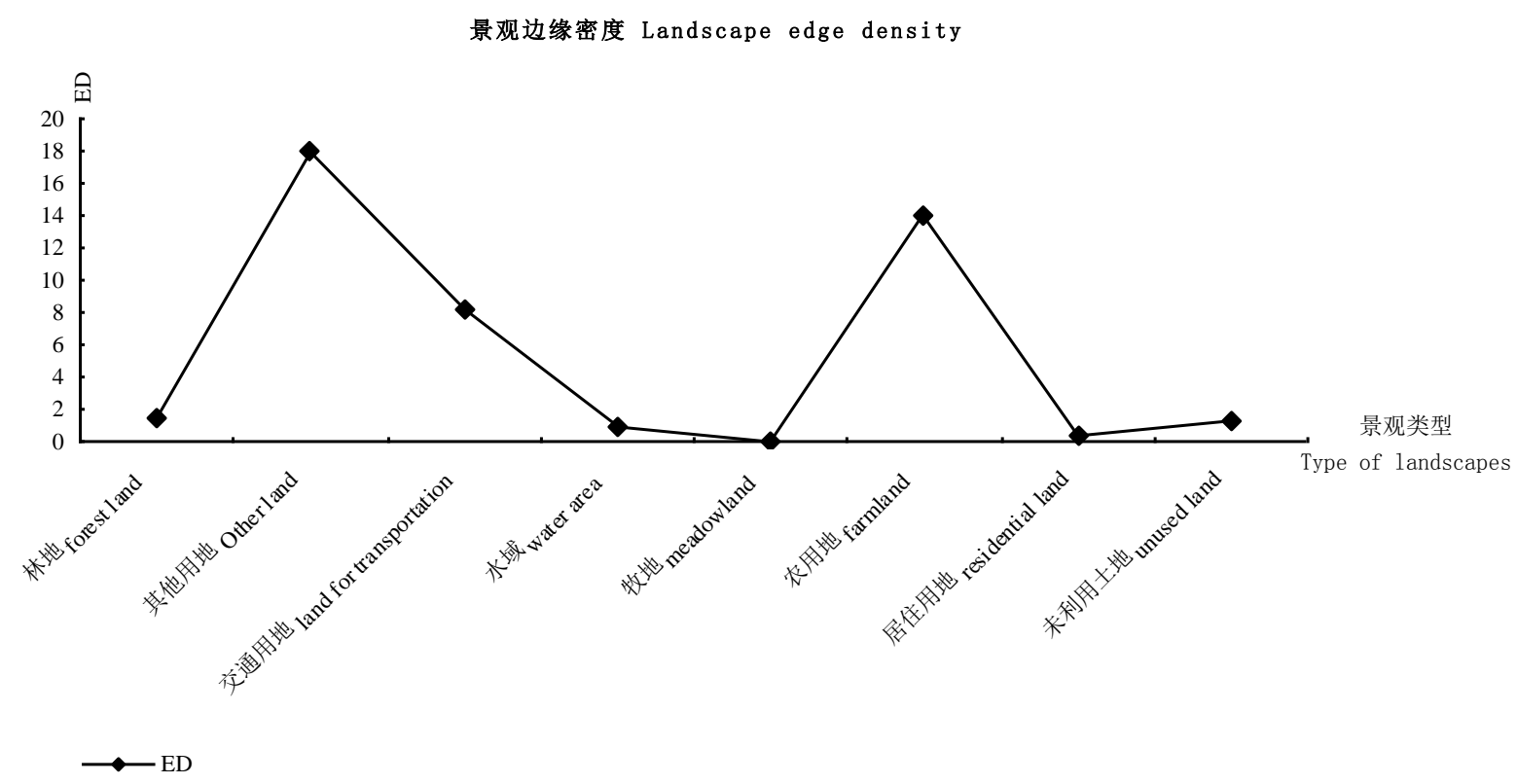

图 6 景观边缘密度折线图

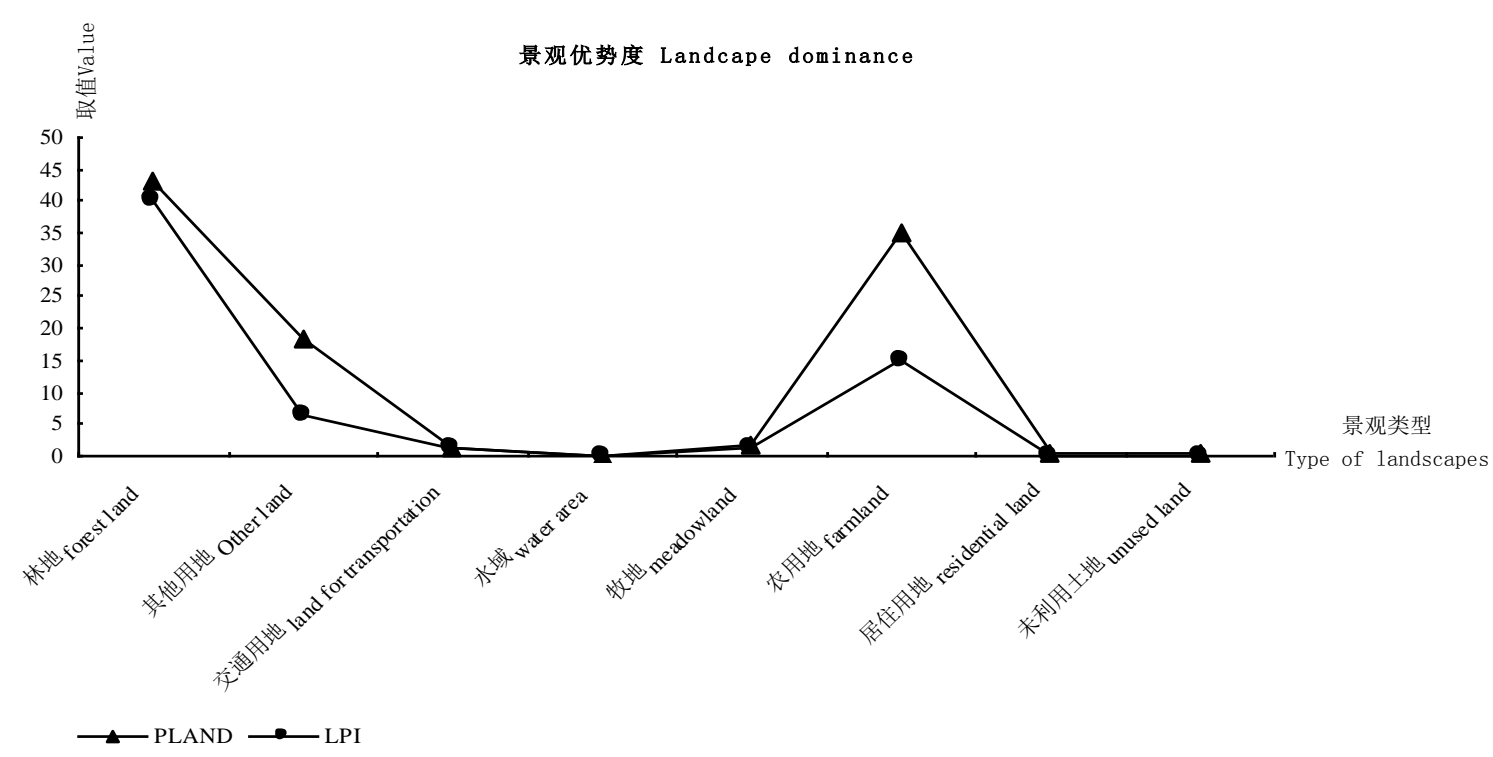

图 7 景观优势度折线图 
2. 1.6 景观优势度分析 在景观的优势度分中, 主要选取 PLAND 和 LPI 值来分析。景观的优势度指数主要 用于衡量城镇景观的结构多样性，确定景观中的优势景观。表 1 和图 7 中可以得出，香兰镇的林地景观优 势度最大, PLAND 指数达 42.9996, LPI 达总体的 39.99\%, 明显高出其余景观类型, 可见香兰镇拥有良好 的林业资源, 土地绿化率较高, 称得上天然的氧吧。除林地外, 农用地的 PLAND 值和 LPI 值也比较高, 可 见香兰镇的农业水平较为发达，人们的农业耕地面积多，农业的开放度高。景观中的优势度类型主要表示 人为活动的强弱和方向, 由 LPI 值反映。有图中可以看出, 林地和农业用地的 LPI 值较高, 说明人们对这 两类景观类型的影响比较大。由此可见，香兰镇的景观类型以林业和农业为主，人们对该地区的林业和农 业发展也较为关注，使其拥有巨大的发展空间与潜力，从而促使整个香兰镇开放性增高。值得一提的是， 香兰镇的水域与居住用地的 PLAND 值和 LPI 值均较低，说明这两项类型用地，亟待开发，迫在眉睫。

\section{2 景观异质性分析}

${ }^{[8]}$ 景观的异质性分析是景观空间格局分析中重要的一部分，在本文中主要选取聚集度（AI）和斑块结 合度指数（COHESION）进行分析，具体数据如下表 2 。

\section{表 2 香兰镇景观异质性指数计算结果表}

\begin{tabular}{lcc}
\hline 景观类型 Type of landscapes & AI (\%) & COHESION \\
\hline 林地 forest land & 536.995 & 89.4992 \\
其他用地 Other land & 230.515 & 19.2096 \\
交通用地 land for transportation & 23.6075 & 1.0357 \\
水域 water area & 14.1725 & 0.2716 \\
牧地 meadowland & 24.435 & 10.2175 \\
农用地 farmland & 435.0325 & 54.3791 \\
居住用地 residential land & 14.8175 & 0.5635 \\
未利用土地 unused land & 3.255 & 0.3617 \\
\hline
\end{tabular}

2.2.1 景观类型的聚集度分析 ${ }^{[9]}$ 景观的聚集度在一定程度上反映了人类活动的强烈程度。在香兰镇的景 观指数中可清晰的看到各类景观类型的聚集度 ( $\mathrm{AI}$ ) 指数都较高, 以林地、农用地和牧地为首, 其他景观 类型次之。可见香兰镇是典型的林业、农业、畜牧业为主的农业景观。交通用地与水域分布则较为零散， 体现了较低的聚集度。

2.2.2 景观类型的连接度分析 ${ }^{[10]}$ 景观类型的连接度指数主要是由景观斑块结合度指数 (COHESION) 量化 的, 具体计算结果如表 2 图 9 。林地、农用地和牧地拥有较高的景观斑块结合度指数, 说明这三类景观用 地有较好的连通性。交通用地、居住用地景观斑块结合度指数适中，除未利用土地外水域则表现出较低的 景观斑块结合度，说明其分布较为分散，整体空间连接性较差。 


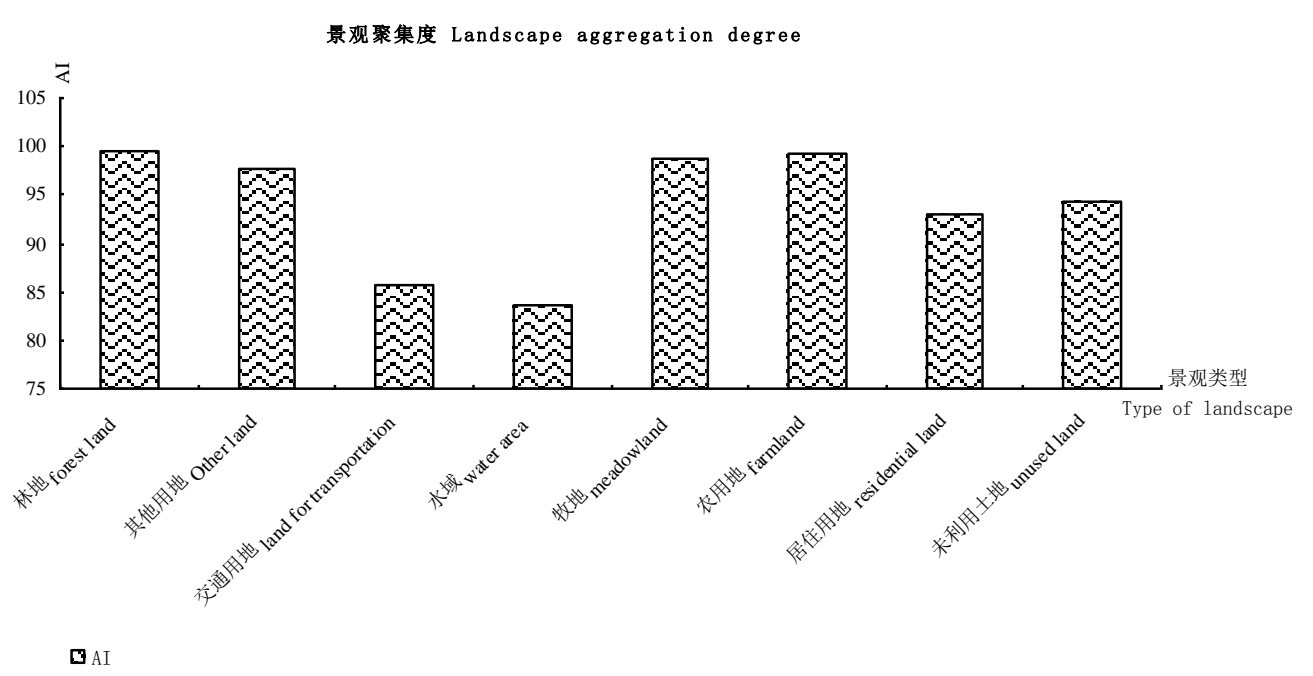

图 8 景观聚集度柱状图

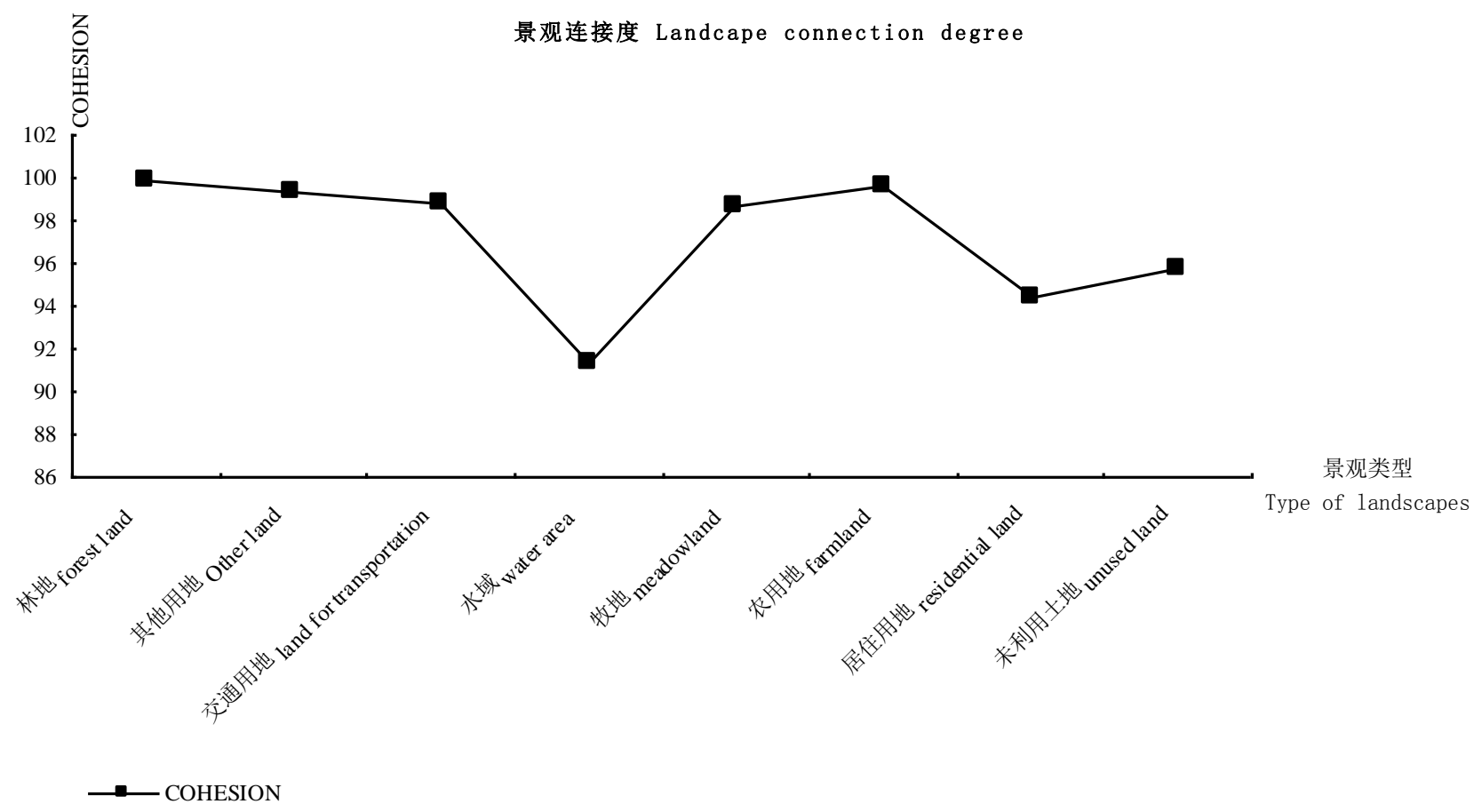

图 9 景观连接度折线图

2.2.3 景观类型的多样性与均匀度分析 ${ }^{[11]}$ 景观类型多样性指数是景观水平上反映景观结构组成的指数, 主要包括斑块丰富度指数和斑块均匀度指数。从表中可得香兰镇景观多样性指数 (SHDI) 为 1.2099, 可见 香兰镇具有较高的景观丰富度, 景观异质性自然也较高。香兰镇景观均匀度指数 (SHEI) 为 0.5507 , 数值 适中, 说明香兰镇景观具有一定程度的景观多样性, 也存在优势景观。这一观点与前文景观优势度分析中 提到的林地景观具有一定高度的景观优势度吻合。 
表 3 景观多样性与均匀度计算结果表

\begin{tabular}{ccccccc}
\hline $\begin{array}{c}\text { 景观指数 Landscape } \\
\text { index }\end{array}$ & SHDI & SIDI & MSIDI & SHEI & SIEI & MSIEI \\
\hline $\begin{array}{c}\text { 计算结果 The } \\
\text { calculation results }\end{array}$ & 1.2099 & 0.6592 & 1.0765 & 0.5507 & 0.7416 & 0.4899 \\
\hline
\end{tabular}

\section{3 景观分形分析}

${ }^{[12]}$ 景观的分形分析主要选取景观形状指数 (LSI)、平均形状指数 (SHAPE)、平均斑块分维数 (FRAC) 和周长面积分维数 (PAFRAC) 来进行分析。下表为香兰镇景观分形指数计算结果表。

表 4 景观分形指数计算结果表

\begin{tabular}{ccccc}
\hline $\begin{array}{c}\text { 景观类型 Type of } \\
\text { landscapes }\end{array}$ & LSI & FRAC & SHAPE & PAFRAC \\
\hline 林地 forest land & 3.027 & 1.0875 & 1.6231 & N/A \\
$\begin{array}{c}\text { 其他用地 Other land } \\
\text { 交通用地 land for }\end{array}$ & 7.6628 & 1.1431 & 2.3679 & 1.228 \\
transportation & 12.8869 & 1.1172 & 1.9732 & 1.5866 \\
水域 water area & 5.678 & & & N/A \\
牧地 meadowland & 2.0829 & 1.2006 & 2.1195 & N/A \\
农用地 farmland & 4.5749 & 1.6128 & 1.4989 & N/A \\
居住用地 residential & 3.25 & 1.0429 & 1.7631 & N/A \\
land & & 1.0875 & 1.4866 & N/A \\
未利用土地 unused & 3 & & 1.4222 & \\
land & & 1.1049 & & \\
\hline
\end{tabular}

2. 3. 1 景观斑块形状分析 ${ }^{[13]}$ 景观斑块的形状主要反映了人类活动对景观的影响程度。 ${ }^{[14]}$ 景观斑块的形状 特征是景观空间格局的重要组成部分, 主要体现景观要素在空间上排列的复杂程度。本文将选取景观的形 状指数和平均斑块分维数对景观斑块形状特征进行研究。 ${ }^{[15]}$ 景观形状指数与其斑块形状的复杂程度成正 比, 即景观的形状指数越大, 斑块的形状越复杂。 ${ }^{[16]}$ 景观斑块的分维数反映景观是形状复杂程度的指数, 分维指数 (FRAC) 越靠近 1, 景观斑块形状越简单; 分维指数（FRAC）越靠近 2 , 景观斑块形状越不规则。 当几个面积相等的景观类型进行比较时, 景观的分维数与景观斑块的周长、景观斑块的复杂程度成正比。 如图所示, 在香兰镇中交通用地的景观形状指数最大, 可见交通用地的景观形状较为复杂。对比图中的景 观斑块的分维数 (FRAC), 可以看出, 农用地的景观斑块的分维数为 1.0429 , 与其余景观类型的指数相比 更接近 1 , 所以农用地的景观斑块形状最为规则, 形状最为简单。而牧地的景观分维指数最接近 2 , 故其 形状最为复杂。

2. 3.2 景观分形特征分析 ${ }^{[17]}$ 在景观分形分析中用地边缘形态的规则性分析是其主要内容, 而景观的边缘 
形态主要由景观周长面积分维数 (PAFRAC) 决定, ${ }^{[18]}$ 周长面积分维数 (PAFRAC) 公式如下:

$$
\text { PAFRAC }=\frac{2}{\left[n_{i} \sum_{j=1}^{n}\left(L n p_{j i} \bullet L n a_{i j}\right)\right]-\left[\left(\sum_{j=1}^{n} L n p_{i j}\right)\left(\sum_{j=1}^{n} L n a_{i j}\right)\right]}
$$

${ }^{[19]}$ 式中: $p_{i j}$ 为斑块 $\mathrm{ij}$ 的周长; $a_{i j}$ 为斑块 $\mathrm{ij}$ 的面积; $n_{i}$ 为景观内斑块类型 $\mathrm{i}$ 包含的斑块数量。

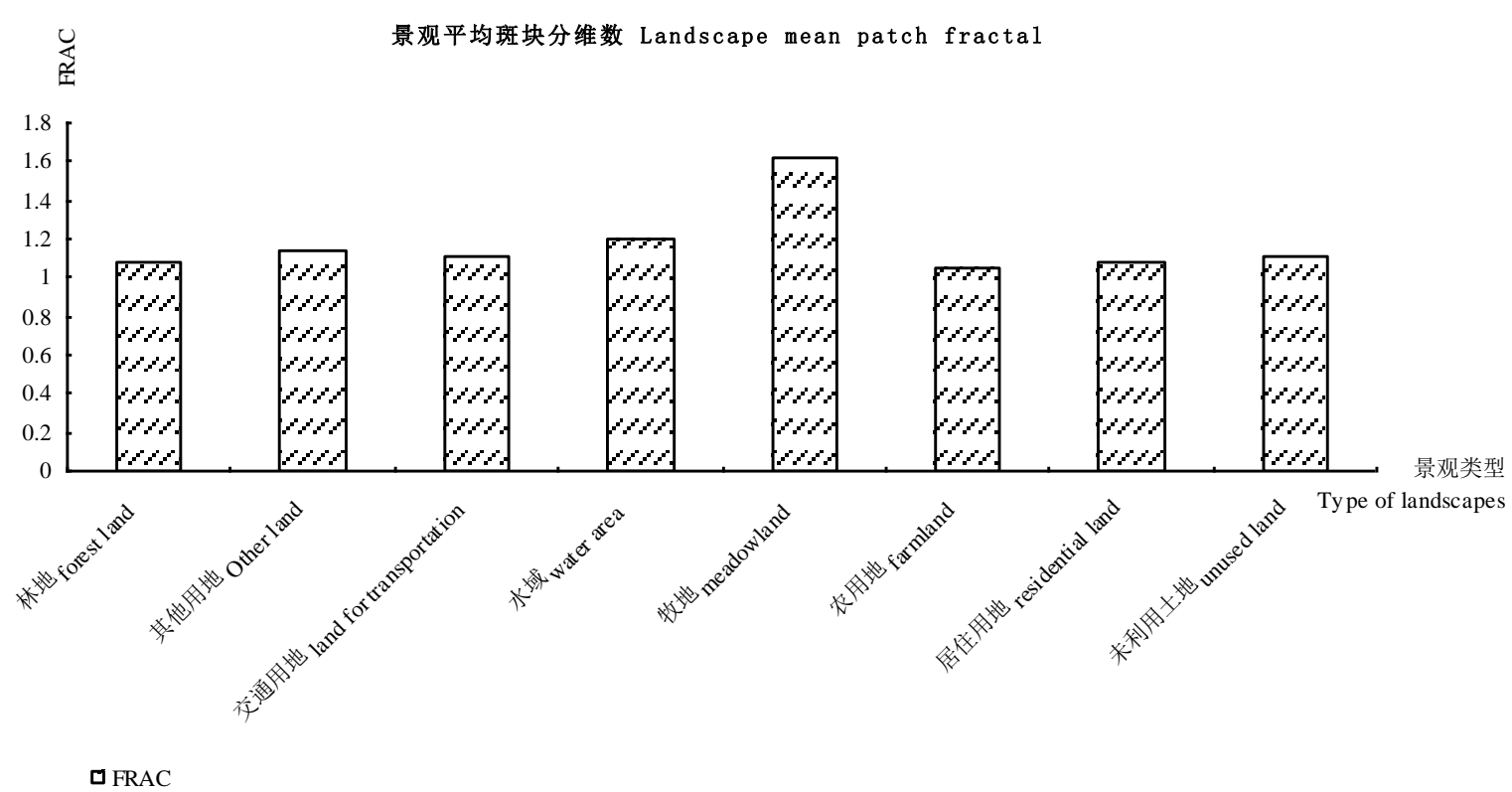

图 10 景观平均斑块分维数指数柱状图

${ }^{[20]} \mathrm{PAFRAC}$ 的取值范围为 $1^{\sim} 2$ 。当景观周长面积分维数越接近 1 , 景观的周长越简单; 当景观周长面积 分维数大于 1 时, 景观的周长已不再是简单的几何形状; 当景观周长面积分维数刚好等于 1.5 时, 景观板 块形态镶嵌结构处于不稳定状态; 当景观周长面积分维数接近 2 时, 景观周长通常呈现弯曲或盘旋的形态。 ${ }^{[21]}$ 由于在研究景观周长面积分维数 (PAFRAC) 时采用的是回归分析法, 回归分析是建模和数据分析常用的 方法, ${ }^{[22]}$ 主要研究自变量与因变量之间的关系, 因此在研究时会遇到样本问题。 ${ }^{[23]}$ 即当斑块数目 (NP) 少 于 10 时, 景观周长面积分维数 (PAFRAC) 是不确定的, 用 N/A 来表示。

从表中的数据结果可以看出, 景观斑块数目超过 10 的, 只有其他用地和交通用地两个景观类型, ${ }^{[24]}$ 其中其他用地的 PAFRAC 值处于 1 与 1.5 之间, 说明其他用地的景观边缘形态已不再是简单的几何形状。 ${ }^{[25]}$ 而交通用地的 PAFRAC 值处于 1.5 与 2 之间, 说明香兰镇的交通用地呈复杂的几何形状, 但没有达到弯曲 或盘旋状态。交通用地边缘形态不规则大大影响了香兰镇的交通状况, 对其经济发展也会造成不小影响。 
表 5 景观斑块数与周长面积分维数计算结果表

\begin{tabular}{ccc}
\hline 景观类型 Type of landscapes & NP(个) & PAFRAC \\
\hline 林地 forest land & 6 & N/A \\
其他用地 Other land & 12 & 1.228 \\
交通用地 land for transportation & 17 & 1.5866 \\
水域 water area & 8 & N/A \\
牧地 meadowland & 4 & N/A \\
农用地 farmland & 8 & N/A \\
居住用地 residential land & 5 & N/A \\
未利用土地 unused land & 9 & N/A \\
\hline
\end{tabular}

\section{4 景观格局分析结果与评价}

景观指数定量分析是将景观空间格局用真实而具体的数据描绘景观格局的一种分析方法，通过对斑块 镶嵌体的数量、密度、形状等特征分析, 得出景观在空间格局中的劣势, 使进一步的规划工作具有科学性 与目的性。图 11 为景观空间格局示意图, 将上文的研究过程进行总结。

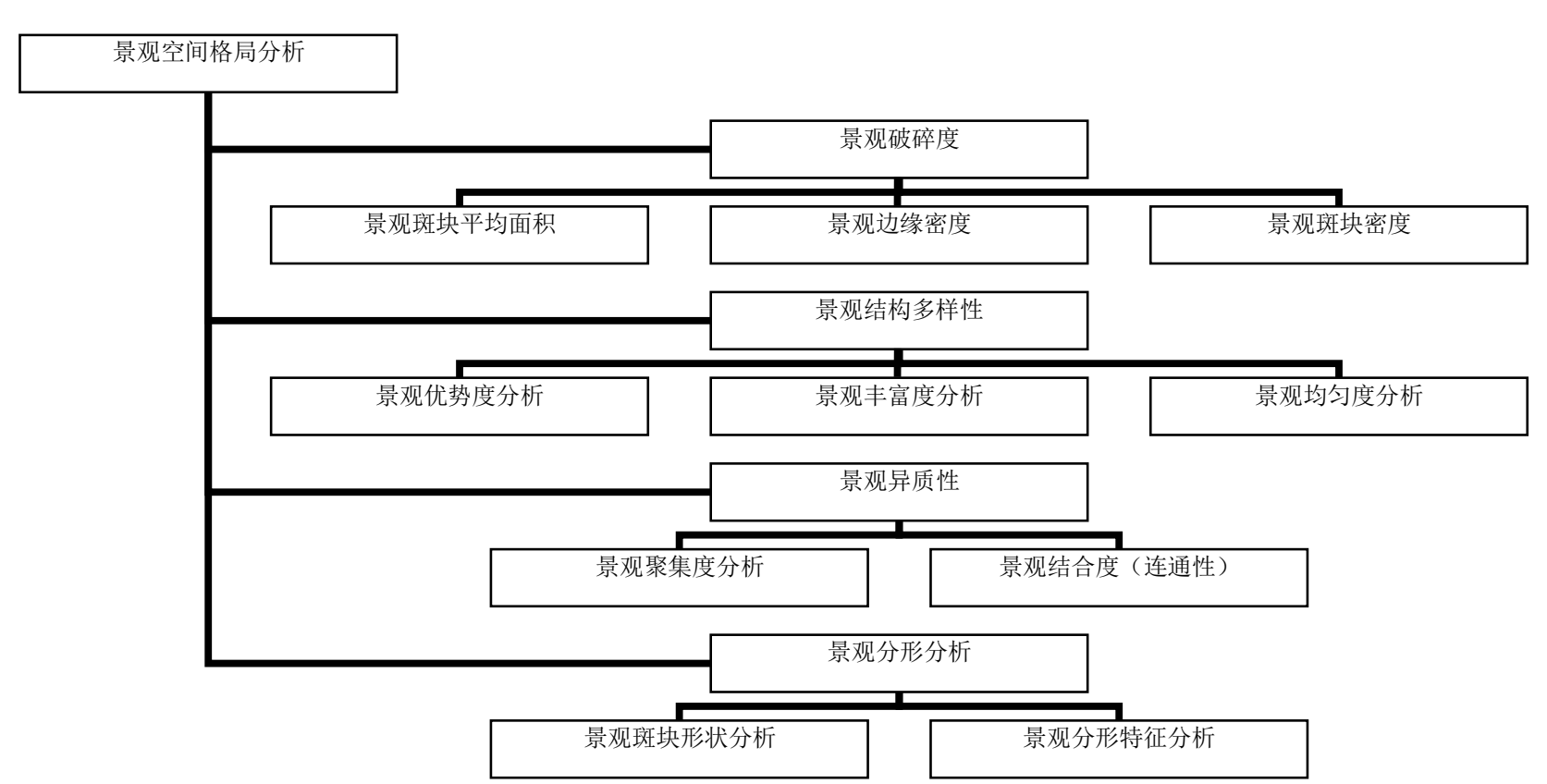

图 11 景观空间格局分析示意图

从景观格局结构即斑块一廊道一基质的角度来看, 香兰镇是以林地为基质, 交通道路和水域作为廊道 连接, 农用地、牧地、居住用地, 其他用地为其重要斑块。由此可见, 香兰镇现阶段所呈现出的景观格局 状况是以农林景观主, 异质性和丰富度适宜。农林用地面积最大, 占全镇的大部分区域, 从而大大提高了 全镇的农林生产力, 但水域和居住面积较小、交通用地景观边缘破碎化严重、道路的形态过于复杂、未利 用土地面积较小土地资源匮乏等问题一一通过景观格局指数暴露, 应合理利用当地土地资源, 调整景观格 局, 从而使其健康发展。 


\section{3 景观空间结构优化设计}

任何景观都是由不同生态系统组成的镶嵌体，不管其性质如何，其组成都可以分为斑块、廊道和基质。 斑块是在外貌上与周围地区有所不同的一块非线型区域，廊道是与斑块相区别的线状或带状区域，基质则 是范围广大、连接度最高并且在景观功能上起着优势作用的景观要素类型。景观格局正是由这三种景观要 素在数量、大小、类型、形状及在空间上的不同组合形式构成的。斑块、廊道、基质是景观生态规划中最 合理的对空间格局进行规划设计的语言模式。景观生态规划中的格局是指空间格局，广义上讲，它包括景 观组成单元的类型、数目以及空间分布与配置。景观格局是景观异质性的具体表现, 是景观功能的主导, 影响着景观间能量的交换与传递。为解决在香兰镇景观空间结构分析时所出现的诸多问题, 根据景观格局 规划设计理论对香兰镇景观进行组分规划分析设计, 主要指对其景观进行斑块、廊道和基质的结构优化设 计。对香兰镇空间结构进行功能规划与空间配置进行重组, 从而组建出不同功能的区域, 平衡景观生态系 统与空间结构的关系。景观组分的规划设计是景观空间结构优化设计的基础, 是以景观要素为核心的生态 系统构建。

\section{1 景观斑块优化}

景观中的斑块主要分为五类: 干扰斑块、残存斑块、环境资源斑块、引进斑块和再生斑块。由于各类 斑块的性质、分布、组合及动态、功能的不同对景观的异质性、动态及功能均有影响。就总体而言, 斑块 在景观中主要有三种功能: 栖息地、源和汇。具体而言, 斑块的大小与物种的丰富度相关、对景观中的物 质流与能量流有所影响; 斑块的形状、边界形状又对景观中的生态流有所影响; 而斑块的空间配置又决定 着生物体能否顺利迁移。景观中应有内缘比很大的等径大斑块为敏感内部种提供栖息地, 同时大斑块间要 用小斑块、廊道或踏脚石进行连接, 以便为边缘种提供栖息地或迁移的通道。

表 6 斑块大小与斑块数目对景观不同影响对照表

斑块大小 大型斑块 有效维持和保护物种多样性

小型斑块 可广泛分布在人为景观中, 提高景观的异质性和多样性, 充当生 物栖息地

斑块数目 斑块数目多

斑块数目少
景观和物种的多样性高, 如斑块数目过多则景观破碎度高 物种生境减少，物种灭绝的危险性大增

斑块规划设计的核心是斑块大小、斑块数目、斑块形状和斑块位置的规划设计。表 6 为斑块大小与斑 块数目对景观不同影响对照表。而最优的景观格局是由几个大型自然斑块组成（大型斑块数目控制在 4 × 个, 确保景观结构与功能的稳定性) 并与众多分散在基质中的小斑块相连, 形成一个有机整体。而斑块形 状的生态学效应主要是斑块的边缘效应, 紧凑和圆形的斑块由于减少了外部影响的接触面而有利于保护内 部物种, 但同时也不利于与外部的生态交换。因此设计连续的斑块有利于物种的扩散与保护, 相邻的斑块 间有利于物种交换，大大增强了生物群体的抗干扰能力。就单一斑块而言，一个理想的斑块应该包括一个 较大的核心区和一些有导流作用及与外界发生相互作用形状各异的缓冲带, 与流具有相同的延伸方向。在 香兰镇的景观格局定量分析中可知, 其景观斑块类型主要包括林地、农田、牧地、居民区、交通用地、水 域、其他用地和未利用土地, 林地与农田充当整个景观的大型斑块, 且均分为一大三小四个斑块, 其中面 
积最大的林地斑块位于香兰镇的西部, 其余三个面积较小的林地斑块分别相邻于牧地斑块与水域斑块; 面 积最大的农田斑块主要集中在香兰镇的东部, 其余三个斑块分别镶嵌于牧地斑块、居民区斑块、林地斑块。 在所有用地类型中, 牧地斑块最为连续, 且与林地斑块、农田斑块、水域斑块、居民区斑块相接。但就个 体斑块而言, 没有呈现出明显的核心区与缓冲带, 这一点在进一步的规划设计中应给予关注。结合以上分 析, 基于香兰镇景观结构布局分散, 景观类型复杂, 各景观类型分布存在诸多不足之处, 故将部分景观斑 块进行重组, 规划成以林、农、居为主的功能组团。其中林地与农田景观斑块面积最大，居住用地景观斑 块面积较小, 可在林地中扩大居住用地, 整合分散的居住用地。将部分居住用地与林地结合, 也可大大提 高居住区的绿化率。

图 12 为城镇建设用地斑块规划图, 通过在居住区、农牧区、林地、水域外围建设绿化隔离带、公共 绿化公园、生态防护林将香兰镇建设区中破碎的建设用地外围的绿地斑块有效的联系起来, 减轻景观的破 碎化程度的同时发挥了生态屏障功能，保护区域的生态平衡。

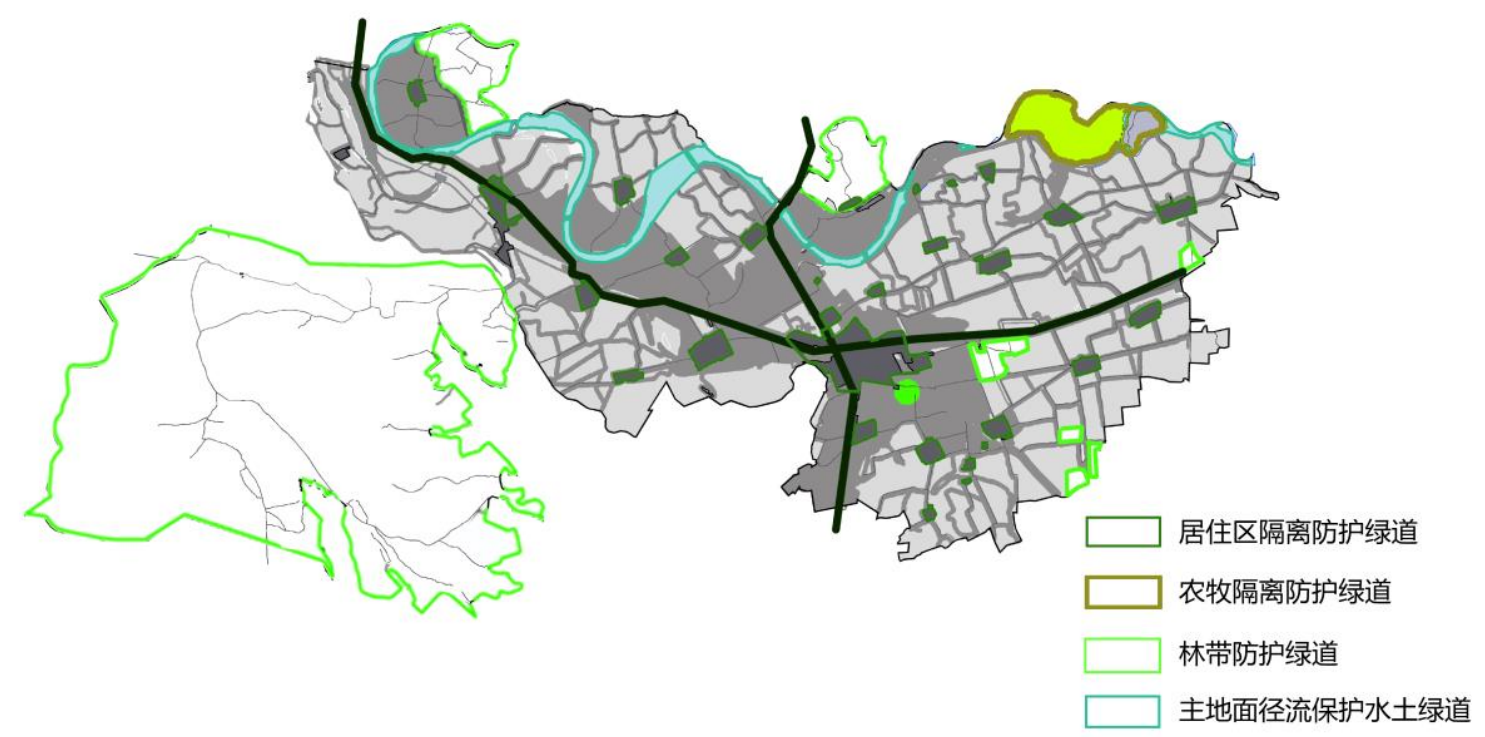

图 12 城镇建设用地斑块

\section{2 景观廊道优化}

景观中的廊道主要分为五类: 环境资源廊道、干扰廊道、残存廊道、种植廊道和再生廊道。同一条廊 道可以同时具有栖息地、源、汇、通道、屏障和过滤的多重功能。具体而言, 廊道的功能与其结构密切相 关，廊道的曲度、宽度、形状、组成内容、连接度、连通性、内环境及与周围斑块或基质的空间关系等结 构特征上的不同对景观的生态过程和功能产生不同影响。

廊道的规划设计，主要涉及廊道数目、廊道构成、廊道宽度和廊道形状等要素。廊道的数目主要是由 规划区内生物通道、自然廊道和人工社会经济需求而确定的, 并非廊道数目越多越好, 但主要的廊道应保 留一定数量规模。对于生物通道而言, 廊道最好应由本地植物种类组成, 并与作为保护对象的残遗斑块具 有相近的物种和生境。本地物种具有适应性强, 使廊道连接性增高, 有利于物种扩散和迁移, 同时有利于 残遗斑块的扩展。廊道的宽度在于廊道所保护的对象, 做到宜宽则宽, 易窄则窄。廊道在空间上的形态主 要有直线和曲线两种, 自然廊道多曲线, 人工廊道多直线。在景观生态规划中, 直线和曲线的确定关键在 于对自然过程和自然格局的整体性和对较高生态效应的追求。 
3.2.1 带状廊道优化 在香兰镇的景观格局分析中得知, 香兰镇部分斑块景观破碎度高, 故利用带状廊道 连接残留的绿地斑块, 使其成为城镇居住生活区输送生态的绿色廊道。在原有的林地、农田、牧地、水域、 交通用地和居住区外围建设一定宽度的隔离绿化带, 形成景观缓冲区, 从而有效提高景观的稳定性也改善 了景观的生态环境。

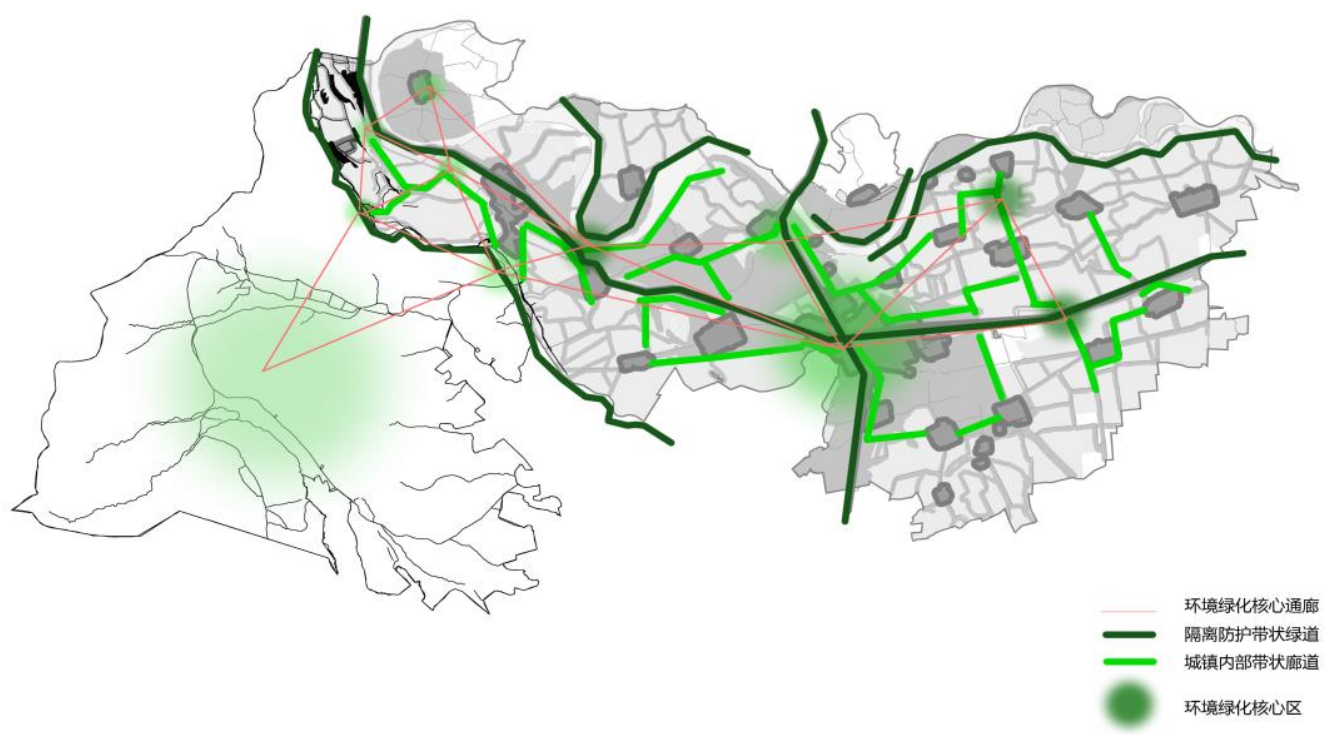

图 13 带状廊道优化

3.2 .2 线状廊道优化 香兰镇的线状廊道优化主要指对其交通用地的优化。交通用地属人工廊道, 呈直线 状, 具有通道与屏障作用。根据香兰镇景观格局定量分析可知, 交通用地廊道数目过多, 过于繁杂, 且边 缘形态不规则, 受干扰程度大, 景观分布不均衡, 在进一步的景观规划中亟待解决。交通用地景观斑块面 积也较小，可以和景观斑块面积最大的景观类型结合，在林地景观中建供休闲娱乐的体育公园，从而增大 交通用地斑块面积, 降低林地景观斑块边缘形态的复杂性, 提高全镇的交通运输能力, 促进贸易发展。

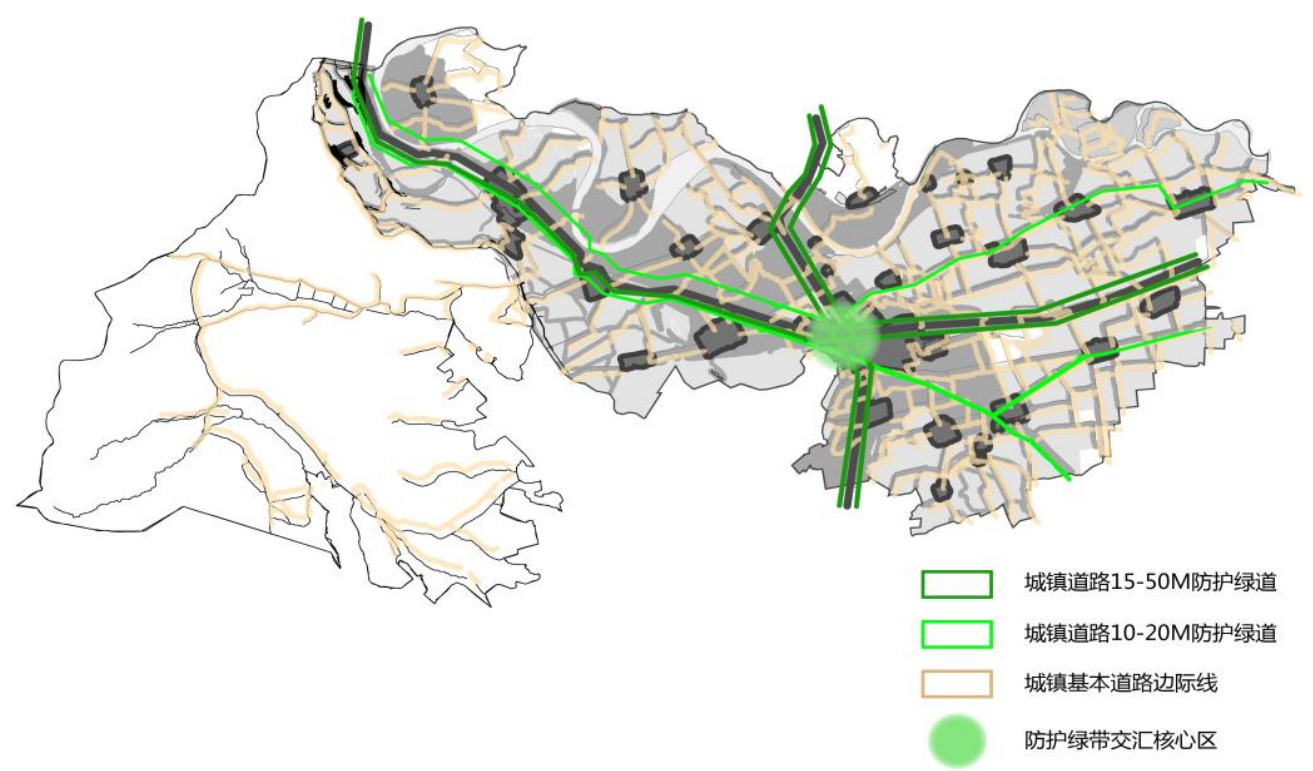

图 14 城镇道路线状廊道优化 
3.2 .3 河流廊道优化 水域多属自然廊道, 呈弯曲状, 多与农田、牧地相接, 在香兰镇的景观生态系统中 作为物质、能量和信息渗透、扩散的通道，极大的促进了景观融合与景观多样性，是景观镶嵌结构更加复 杂。水域对景观格局的影响不仅体现在调节生态平衡上还体现在疏通运输力度上。香兰镇的水域分散且景 观面积较小，因此在保护河流自然形态的基础上应加强地表水与地下水的循环，减少洪涝灾害，维持生物 多样性，降低景观的破碎化程度。在河流廊道优化设计中应在现有河流廊道完成保护的基础上进行规划建 设。

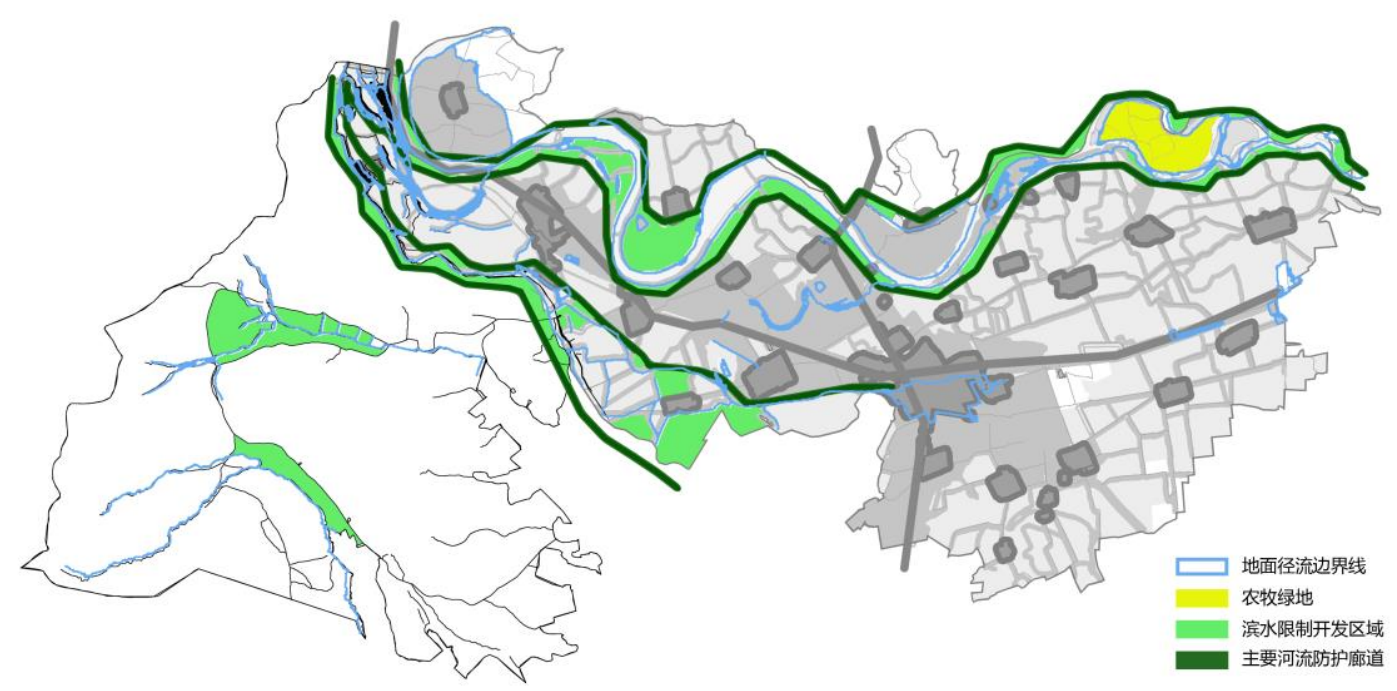

图 15 河流廊道分析优化

\section{3 景观基质优化}

香兰镇正处于山地与平原结合处，因此其自然界面属于山地、平原交错带。山地与平原是两大不同属 性的地理单元, 在生态学中被划分为山地生态系统和平原生态系统。在其二者相连接的过渡地带内, 存在 着两大系统各生态因素之间的强烈协同作用, 多种应力的交互影响和相干效应, 这一地带异质性强, 信息 丰富, 也是相对山地和平原各种自然, 社会经济要素水平分布的突变地带, 有着资源要素分布最大梯度和 物流能流的最大流量。这种山地与平原之间所存在的地带, 成为山地与平原相互作用的交错地带。交错带 自由度较高, 选择余地大, 人类对资源的掠夺性开发利用也往往较强, 容易造成环境的破坏, 资源再生能 力下降等一些列问题。根据上文的斑块优化、廊道优化和基质的优化结合香兰镇所处的自然界面，对香兰 镇进行整体的景观格局规划研究。主要集中于：居民区的再次规划, 解决其分散的布局, 与林地、农田建 立合理的连接; 交通用地的再次规划, 解决其数目多, 结构繁杂, 景观分布不均衡的缺点; 增大林地与农 田、牧地、居民区的连接度; 在优化林地斑块的同时可以将农用地的面积提高, 开发农田，将农林结合形 成不同的林业类型, 从而增加了林地的物种多样性, 扩大农用地面积。使牧地与林地、农用地相结合, 更 好的实现村镇与林地的融合，将香兰镇真正打造成以农、林、牧为主的汤原县先进镇。 


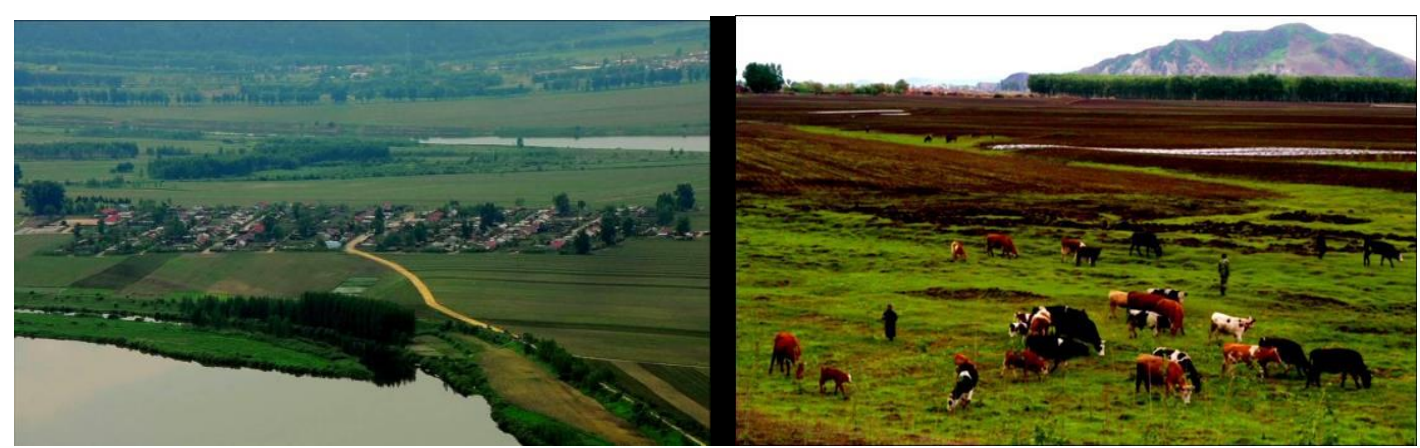

图 16 牧、林、农用地结合

\section{4 结 论}

基于在 GIS 中对景观格局的定量分析，依据景观生态规划的相关理论，从景观组分和格局组合两个方 面对香兰镇的斑块、廊道和基质进行分析并提出相应的规划策略，再结合香兰镇所处自然界面和其景观生 态功能和空间结构存在问题对其进行整体规划。从而解决了居住用地和水域的景观斑块面积较小，景观连 接度低, 聚集度低, 景观优势度较低, 处于分散排布状态; 交通用地景观破碎化程度较大, 也存在景观聚 集度低的问题，且交通用地景观边缘形态复杂，大大阻碍了香兰镇的经济发展; 其他用地、农用地和交通 用地景观被边缘割据的程度大, 受周围人为环境影响巨大; 林地斑块与居民区斑块、牧地斑块、农田斑块 连接度小等相关问题。着重处理其交通用地、居民用地和水域聚集度低、交通用地景观破碎化程度大边缘 形态复杂等问题。本研究以香兰镇的景观格局优化为例, 旨在推进小城镇景观格局优化的研究。首先要对 现有景观格局指数进行深入研究，通过景观斑块平均面积、景观边缘密度、景观斑块密度对景观破碎度进 行评定; 通过对景观优势度、丰富度、均匀度的分析得出景观结构多样性的程度和优势景观; 通过对景观 聚集度和结合度的分析了解景观的异质性与连通性; 通过对景观的分形分析了解景观斑块的边缘复杂性。 通过一系列的景观指数分析后得出景观格局中的问题，对景观分别进行斑块、廊道和基质的优化，从而形 成合理的景观格局，优化景观生态环境。

\section{参考文献}

[1] 专著一一余新晓, 牛健植, 冯仲科. 景观生态学 [M]. 第一版. 北京：高等教育出版社，2006.

[2] 专著一一张娜. 景观生态学 [M]. 第一版. 北京: 科学出版社, 2014(5) : 207-208.

[3] 学位论文一一谭云风. 基于 GIS 和 Fragstats 的团结镇景观格局优化研究 [D]. 东北林业大学硕士毕业论文, 2014.

[4] 专著中的析出文献一一宋海宏, 谭云风. 哈尔滨东郊低山丘陵区土地利用景观格局分析 [C]//Wu Xun, Chen Weizhen, Yang Wei jun, 等. Hydraulic Engineering and Sustainable City Development ш. Applied Mechanics and Materials. 杭 州: Trans Tech Publications, 2014: 514-518.

[5] 专著一一张娜. 景观生态学 [M]. 第一版. 北京: 科学出版社, 2014（5):228-229.

[6] 期刊一一郑新奇, 付梅臣. 景观格局空间分析技术及其应用 [M]. 2010（12）110-111.

[7] 期刊一一孟兆江, 贾大林, 刘安能, 等. 调亏灌溉对冬小麦生理机制及水分利用效率的影响 [J]. 农业工程学报, 2003, $19(4): 66-69$.

[8] 期刊一一裴 冬, 孙振山, 陈四龙, 等. 水分调亏对冬小麦生理生态的影响 [J]. 农业工程学报, 2006, 22 (8)：68-72.

[9] 专著——Hansen A, Castri F di. Landscape boundary [M].纽约:Springer, 2014.

[10] 专著一-Iverson L R. Land use changes in Illinois, USA: the influence of landscape attributes on current and historic land use. Landscape Ecology [M]. 2. 1988:45-56. 
[11] 专著中的析出文献——Romme W H. Fire and landscape diversity in subalpine forests of Yellowstone National Park. Ecol Monogr, Ecological Society of America, 2014, 53:145-165.

[12] 专著 - - Shannon C, Weaver W. The mathematical theory of communication[M]. Urbana:Univ. Illinois Press, 2012.

[13] 期 刊 - - Krummel J R, Gardner R H, Sugihara G, et al. Landscape patterns in a disturbed environment [J]. 0ikos, 1987, $48(2): 321-324$.

[14] 期 刊 - With K A,Cris T 0.Critical thresholds in species' responses to landscape structure [J]. Ecology, 1995, 77 (12) :33-35.

[15] 期 刊 - - Dale M R T. Lacunarity analysis of spatial pattern:a comparison[J]. Landscape Ecol, 2010, 15:45-65.

[16] 期刊 - - Brittingham M C,Temple S A. Have cowbirds caused forest songbirds to decline?[J]. Bio - Science, 2015, 44:132-144.

[17] 期刊——Helliwell D R. The effects of size and isolation on the conserbation value of wooded sites in Britain[J]. J Biogeogr, 2013, 4:406-412.

[18] 期刊——Dickman J B, Danielson B J , Pulliam H R. Ecological processes that affect populations in complex landscapes [J]. 0ikos, 2015, 65:443-454.

[19] 期刊——Hardt R A , Forman R L. Boundary form effects on woody colonization of reclaimed surface mines [J]. Ecology, 2011, 60:1345-1365.

[20] 期刊——Krummel J R, Gardner R H , Sugihara G, et al. Ecological processes that affect populations in complex landscapes [J]. 0ikos, 2011, 77:448-459.

[21] 期刊- - Hansen A, Castri F di. the influence of landscape attributes on current and historic land use [J]. Landscape Ecology, 2014, 6:145-156.

[22] 期 刊 - - Iverson L R. Land use changes in Illinois, Landscape patterns in a disturbed environment [J], 0ikos, 2013, 43:245-255.

[23] 期刊——Dale M R T. Lacunarity analysis of spatial pattern Have cowbirds caused forest songbirds to decline?[J]. Bio - Science, 2010, 44:145-164.

[24] 期刊- - Romme W H. Pulliam H R. 2015. Ecological processes that affect populations in complex landscapes [J]. 0ikos, 2014, 33:243-254.

[25］专著一一王云才. 景观生态规划原理 [M], 北京:中国建筑工业出版社, 2014(7) :266-267.

\section{References}

[1] Yu X-X, Niu J-Z,Feng Z-K: “Landscape Ecology”[M], (2006), No.1, p.72-73 (in Chinese)

[2] Zhang N:" Landscape Ecology"[M], (2014), No.5,p.207-208(in Chinese)

[3] Tan Y-F: Research on the landscape pattern optimization of Tuanjie town based on GIS and Fragstats (MS., Northeast Forestry University, China 2014), p31-32(in Chinese)

[4] Song H-H, Tan Y-F:"Landscape Pattern Analysis of Land Use in Low Mount Hilly Land of Harbin Eastern Suburb"[C], Wu Xun, Chen Weizhen, Yang Weijun, ed al. Hydraulic Engineering and Sustainable City Development ш. Applied Mechanics and Materials. Hang Zhou: Trans Tech Publications, Vol. 440 (2014), p.514-518.

[5] Zhang N:“Landscape Ecology”[M], (2014), No.5:p.228-229(in Chinese)

[6] Zheng X-Q, Fu M-C:“Landscape spatial analysis technology and its application", (2010),No.12:p.110-111(in Chinese) 
[7] Meng Z-J, Jia D-L, Liu A-N, et al:"Effect of regulated deficit irrigation on physiological mechanism and water use efficiency of winter wheat" $[\mathrm{J}]$. Transactions of the Chinese Society of Agricultural Engineering,Vol.19(2003),No.4: p.66-69 (in Chinese)

[8] Pei D, Sun Z-S, Chen S-L, et al:"Effects of water stress on physiological and agronomic features of winter wheat" $[\mathrm{J}]$.Transactions of the Chinese Society of Agricultural Engineering,Vol.22(2006), No.8: p.68-72 (in Chinese)

[9] Hansen A, Castri F di:“Landscape Boundaries”[M],(2014),New York :Springer.

[10]Iverson L R:"Land use changes in Illinois, USA: the influence of landscape attributes on current and historic land use"'J]. Landscape Ecology,(2013),No.2:p.45-56.

[11]Romme W H:"Fire and landscape diversity in subalpine forests of Yellowstone National Park". Ecol Monogr,Vol.53(2014),p.145-165.

[12] Shannon C, Weaver W:"The mathematical theory of communication"[M].Urbana: Univ. Illinois Press,(2012)

[13] Krummel J R,Gardner R H,"Sugihara G, et al.Landscape patterns in a disturbed environment”[J],Oikos,Vol.67(2011), p.345-355.

[14]With K A,Cris T O:“Critical thresholds in species'responses to landscape structure"[J]. Ecology,Vol.77(2010), p.33-35.

[15]Dale M R T:“Lacunarity analysis of spatial pattern: a comparison"'[J].Landscape Ecol,Vol.15(2010), p.45-65.

[16]Brittingham M C:"Temple S A".Have cowbirds caused forest songbirds to decline? " [J].Bio -Science, Vol. 44(2015), p. 132-144.

[17] Helliwell D R.: "The effects of size and isolation on the conserbation value of wooded sites in Britain” [J]. J Biogeogr,(2013),No.4:p.406-412.

[18]Dickman J B , Danielson B J ,"Pulliam H R:Ecological processes that affect populations in complex landscapes”[J]. Oikos,Vol.65(.2015),p.443-454.

[19] Hardt R A ,Forman R L:"Boundary form effects on woody colonization of reclaimed surface mines"[J].Ecology,Vol.60(2011),p.1345-1365.

[20] Krummel J R,Gardner R H ,Sugihara G, et al:"Ecological processes that affect populations in complex landscapes”[J]. Oikos,Vol.77(2011),p.448-459.

[21] Hansen A, Castri F di:"the influence of landscape attributes on current and historic land use"[J]. Landscape Ecology,(2014) No.6,p.145-156.

[22] Iverson L R:"Land use changes in Illinois, Landscape patterns in a disturbed environment'[J],Oikos,Vol.43(2013),p.245-255.

[23]Dale M R T:"Lacunarity analysis of spatial pattern Have cowbirds caused forest songbirds to decline?’[J] Bio -Science, Vol. 44(2010), p. 145-164.

[24]Romme W H, Pulliam H R:"Ecological processes that affect populations in complex landscapes”[J]. Oikos, Vol.33(.2015):p.243-254.

[25] Wang Y-C: "Landscape ecological planning principle" [M]. (2014), No.7, p. 266-267(in Chinese) 